\title{
HOMICIDIO DE LA PAREJA EN VIOLENCIA INTRAFAMILIAR. MUJERES HOMICIDAS Y EXENCIÓN DE RESPONSABILIDAD PENAL
}

\author{
Myrna Villegas Diaz*
}

\begin{abstract}
RESUMEN
La neutralidad de género en el lenguaje jurídico y en la interpretación del derecho penal dificulta la apreciación de circunstancias bajo las cuales una mujer sometida a malos tratos en el ámbito familiar puede dar muerte a su pareja, y que puedan conducir a una eventual exención de responsabilidad penal, exención que los tribunales son reacios a otorgar. Las vías posibles oscilan entre las causas de justificación (legitima defensa, estado de necesidad defensivo) y las causas de inexigibilidad (miedo insuperable, fuerza irresistible) siendo preferidas por los tribunales estas últimas, lo que impide entonces considerar que el homicidio del agresor pueda ser una conducta permitida por el derecho, prefiriéndose subsumir la conducta de la mujer dentro de estados mentales anormales.
\end{abstract}

$$
\text { PARRICIDIO - HOMICIDIO - GÉNERO }
$$

\section{Couples bomicide in domestic violence. Female murderers and excemption of criminal liability}

\begin{abstract}
The neutrality of gender in legal language and in the interpretation of Criminal Law hinder the appreciation of certain circumstances under which a woman subdued to violence in a domestic environment can give death to a spouse or partner, and that can conduct to an eventual exemption of criminal responsibility; an exemption that courts are unlikely to grant. The possible paths to recognize them vary between the general defenses (legitimate self-defense, state of necessity) and non enforceability causes (insurmountable fear, irresistible force), being the latter the most preferential in courts, which then impedes considering that the homicide of the aggressor may be a conduct permitted by law, preferring to subsume the female conduct to abnormal mental states.
\end{abstract}

\section{PARRICIDE - HOMICIDE - GENDER}

* Abogada, Doctora en Derecho, Investigadora del Centro de Investigaciones Jurídicas de la Universidad Central, Santiago de Chile.myrnavillegasd@ucentral.cl

Este trabajo forma parte del proyecto de investigación Anillo en Género y cultura SOC 21, del que la autora es coinvestigadora.

Artículo recibido el 30 de marzo de 2010 y aceptado para su publicación por el Comité Editorial el 27 de octubre de 2010. 


\section{Consideraciones GENERALES}

$\mathrm{L}$ a neutralidad de género en el derecho penal, sustentada sobre categorías dogmáticas que nos son enseñadas en las escuelas de derecho con una ausencia notoria de consideraciones de género, determina que en el campo de la criminalización secundaria en delitos contra la vida en contexto de VIF, las interpretaciones de la ley en nombre de la "igualdad" se tornen discriminatorias y gravosas. Pues cuando es el hombre el que golpea a la mujer en términos tales que pudiéramos argumentar la existencia de dolo de matar, normalmente se apreciará dolo de lesionar, bajo el razonamiento de que si hubiese querido matarla la habría matado igual ${ }^{1}$. Son contados los casos en que el hombre es formalizado por parricidio u homicidio tentado o frustrado, y tienen que haber precedido una decena de agresiones anteriores y denuncias ${ }^{2}$. En cambio, cuando es la mujer maltratada la autora de una agresión similar normalmente se apreciará en ella dolo de matar, pues o bien hubo un exceso en la defensa, o ésta fue desproporcionada, o simplemente quería vengarse del marido. Se olvida que el hombre puede matar con las manos, la mujer, por inferioridad física, siempre deberá acudir a un medio más peligroso. Esto, por tanto, impide apreciar el ánimo de defensa (por contra al dolo homicida), o la racionalidad del medio ${ }^{3}$.

A mayor abundamiento, cuando la mujer espera a que el hombre se acueste o se duerma para darle muerte, como única forma de terminar con la violencia en su contra, se argumenta la existencia de alevosía, sin considerar que en una situación de agresión permanente, como sucede en VIF, la mujer necesariamente tiene que esperar la indefensión del hombre para atacar, pues nunca tendrá éxito si se defiende mientras esté siendo agredida. El hombre que mata a la mujer a golpes comete parricidio u homicidio simple, en cambio la mujer que lo mata cuando se duerme, comete parricidio u homicidio calificado ${ }^{4}$. También se acepta que el estado de ebriedad al momento de matar (frecuente en el agresor) afecta el elemento cognitivo del dolo, y podría llegar incluso a atenuar su responsabilidad penal. En cambio, otras alteraciones, como la rabia, el odio de la mujer hacia su agresor, no son consideradas como alteraciones capaces de

${ }^{1}$ Larrauri, E.-Verona, D. Violencia Doméstica y Legítima Defensa. Edit. EUB, Barcelona, 1995, p. 16. Sólo para ilustrar, veamos la defensa de un imputado por el parricidio de su conviviente: "...nunca existió en el imputado la intención de matar a su pareja, sino que a raíz de la manipulación del arma entre ellos, además la víctima ve el arma poco antes, lo que elimina una actitud dolosa; el testimonio del imputado es conteste en un $90 \%$, solo difieren de la manera de utilizar el arma (...) la circunstancia de una persona presionada por los hechos, le permite establecer una duda razonable acerca del dolo del imputado. Luego minimiza o pone en duda el contexto de violencia intrafamiliar". Cabe señalar que el imputado después de disparar contra su conviviente tras una seguidilla de años de malos tratos, alteró el sitio del suceso intentando eludir su responsabilidad. Sentencia $6^{\circ}$ TOP de Santiago, 7-12-2009, RIT 569-2009, RUC 0800638596-7.

${ }^{2}$ Sentencia $3^{\circ}$ TOP de Stgo, 28-03-2007, RIT 17-2007, RUC 0600435442-5.

3 Se coincide en estas apreciaciones con Larrauri y Verona, ob. cit., pp. 16, 19 y ss. citando las Sentencias del Tribunal Supremo de 13-10-93; RA 1993/7709; 20-12-1989; RA 1989/9683; 9-12-1993; RA $1993 / 9942$.

${ }^{4}$ También en esta apreciación, Larrauri, E.-Verona, D. ob. cit., pp. 20-21. Cita Sentencia Tribunal Supremo de 29-6-1990; RA 1990/7306. 
atenuar el conocimiento y voluntad de realización. Por tanto, el dolo no se excluye, y la responsabilidad penal tampoco se atenúa.

El presente artículo intenta dar una visión panorámica actual, dirigida especialmente a los operadores del sistema penal, sobre la discusión doctrinaria y jurisprudencial respecto del tratamiento jurídico penal para la mujer homicida de su pareja en contexto de VIF, a fin de argumentar a favor de la exención de su responsabilidad penal, sumándome a los esfuerzos comenzados por otras autoras en esta área ${ }^{5}$, y que transitan por dos vías: la una, que aprecia una causal de justificación (legítima defensa, estado de necesidad defensivo), la otra, que aprecia la existencia de una causa de inexigibilidad en la conducta (miedo insuperable, fuerza irresistible). No está de más recordar que la causal de justificación determina un comportamiento que el derecho autoriza de concurrir los requisitos que la ley señala (afectación de antijuridicidad), en cambio, la causal de inexigibilidad únicamente afecta la culpabilidad, quedando intacto el injusto penal. Se intentará demostrar que la muerte del agresor en contexto de VIF es un comportamiento justificado y no meramente exculpado.

\section{Causales de justificación}

\section{II.1. Legítima defensa}

\section{Fundamento y concepto}

Para que se pueda actuar en defensa es preciso que haya necesidad de defenderse, esto es, necesidad de hacer algo para repeler una agresión o impedir que se consume: "Desde el momento que una agresión ilegítima pone en peligro un bien jurídico de un individuo, y aunque esté presente la fuerza pública y pueda intervenir (incluso suficientemente), desde ese momento surge la necesidad de defensa para el bien jurídico"6. Por eso, no puede hallarse el fundamento de la legítima defensa en la imposibilidad de protección por parte de los órganos estatales en un momento dado ${ }^{7}$, pues ello conduce a otorgarle un carácter subsidiario frente al Estado, que la doctrina está conteste en rechazar $^{8}$. Sin embargo, y como veremos más adelante, este carácter subsidiario de la eximente es normalmente esgrimido para negar su concurrencia en casos de VIF.

${ }^{5}$ Al respecto se recomienda el trabajo ya citado de Elena Larrauri y Daniel Verona en España, y el de Luz Rioseco en Chile, Rioseco, L. "Culminación de la violencia doméstica: mujeres que asesinan a sus parejasdefensas penales posibles”, en Facio, A. Fries, L. (Eds.), Género y Derecho, Colección contraseña, Estudios de Género, Serie Casandra LOM Ediciones/ La Morada, Santiago de Chile, 1999, pp. 707-735.

${ }^{6}$ Luzón Peña, D. Aspectos esenciales de la legítima defensa. Bosch, Barcelona, 1978, $2^{\text {a }}$ edición 2002, p. 37.

${ }^{7}$ Cury, E. Derecho Penal. Parte General, Universidad Católica, Santiago de Chile, 2005, p. 372. En el mismo sentido Bullemore, V. y otro. Curso de Derecho Penal, Tomo II. Teoría del Delito, LexisNexis, Santiago de Chile, 2005, p. 56.

${ }^{8}$ Así en la doctrina chilena Cury, ob. cit., p. 375, Etcheberry, A. Derecho Penal, Tomo I, Edit. Jurídica, Santiago, Chile, 1997, p. 256. En la doctrina española, por todos, Baldó Lavilla, F. Estado de necesidad y legítima defensa, Bosch, Barcelona, 1994 p. 309. 
Mayoritariamente se estima que el fundamento está en la "protección individual” y en el "prevalecimiento de un derecho", prevalecimiento que vendría a dar a la legítima defensa un fin de prevención general ${ }^{9}$. Siguiendo a Luzón, pensamos que el fundamento de la legítima defensa está en la "necesidad de defensa" ${ }^{10}$ y que los fines preventivos generales (en cuanto reafirmación del derecho violentado por el agresor) quedan subordinados a esta necesidad de defensa. Esta idea, unida a la relativa amplitud de los bienes jurídicos defendibles (persona o derechos, propios, del cónyuge, de parientes o extraños), pone de manifiesto que en casos de VIF hay una situación en la que la legítima defensa puede tener asidero, pues el agresor abusando de su poder crea un verdadero clima de temor (o terror) en su familia, que lleva a la mujer y los hijos a encontrarse en una especial situación de vulnerabilidad, no siendo posible exigir que en el momento tome otras vías de solución (huir, llamar a carabineros), así como tampoco es necesario un acometimiento físico in actum de parte del agresor para que pueda configurarse la legítima defensa en la mujer que lo lesiona o le mata. Bastaría con una amenaza cierta que anuncie un ataque inmediatamente posterior. Tal es el caso también de la prostituta que se defiende del proxeneta. Desarrollemos esta idea.

\section{Requisitos de la legítima defensa}

Conforme al art. $10 \mathrm{~N}^{\circ} 4$ del CP, los requisitos de la legítima defensa son: a) agresión ilegítima, b) necesidad racional del medio empleado para impedirla o repelerla, c) falta de provocación suficiente por parte del que se defiende ${ }^{11}$. De estos requisitos, los núcleos problemáticos en materia de género son: En su parte objetiva, la actualidad e inminencia de la agresión y la necesidad racional del medio empleado. En su parte subjetiva, la falta de voluntad de defensa.

${ }^{9}$ Roxin, C. Derecho Penal. Parte General. Tomo I.: Fundamentos. La estructura de la teoría del delito, Trad. y notas DM. Luzón Peña, Miguel Díaz y García Colledo, Javier de Vicente Remesal, Civitas, Madrid, 1997, pp. 608-609. En la doctrina nacional, asumen esta postura Garrido Montt, para quien el fundamento de la legítima defensa es dual: "la protección de los intereses individuales y la confirmación del derecho", Garrido Montt, M. Derecho Penal. Parte General. Tomo II. Nociones fundamentales de la teoría del delito. $4^{\mathrm{a}} \mathrm{ed}$. Edit. Jurídica de Chile, Santiago de Chile, 2005, pp. 165 y s. Politoff y Ortiz, encuentran este fundamento en la "necesidad racional" en cuanto "la reacción autorizada por el ordenamiento jurídico es indispensable para salvar el interés del agredido y amparar al mismo tiempo al orden jurídico que lo protege", Politoff, S.-Ortiz, L. et al., Texto y Comentario al Código Penal Chileno, Editorial Jurídica de Chile, Santiago de Chile, 2003 , p. 128 .

${ }^{10}$ En similar sentido, Juan Bustos y Hernán Hormazábal fundamentan en la "necesidad racional de defensa" y en la necesidad de "mantenimiento del orden jurídico" y Baldó Lavilla en la "defensa necesaria". Bustos, J.-Hormazábal, H. Lecciones de derecho Penal. Editorial Trotta, Barcelona, 1999, p. 129; Baldó Lavilla, F, ob. cit., p. 263.

${ }^{11}$ Estos requisitos son idénticos a los del CP español (art. 20.4). Una fórmula interesante es la del CP alemán, el que exige directamente la "necesidad de defensa" a la que antes hacíamos alusión. Así el $\$ 32$ señala en lo pertinente que: "Se considera legítima la defensa que resulte necesaria para repeler una agresión antijurídica actual contra uno mismo o contra un tercero". 


\section{a. Agresión ilegítima}

La ilegitimidad de la agresión del marido o cónyuge hacia su conviviente es indiscutible, y se sanciona en la Ley $\mathrm{N}^{0} 20.066$ como una simple falta (art. 8) o como un delito (art. 14). El problema se presenta en relación a la actualidad de la agresión en el caso de la mujer homicida, pues normalmente para apreciar la legítima defensa se exige que ella se esté produciendo en el instante en que la mujer se defiende matando. Como se ha esbozado antes, esta interpretación, aparentemente igualitaria para todos los casos, no se ajusta a la realidad de la VIF, pues la mujer no puede defenderse con éxito en el momento en que se está produciendo el ataque. Hay que tener en cuenta que una agresión ilegítima no es sólo aquella que lesiona un bien jurídico, sino también aquella que "pone en peligro un bien jurídico"12, un "peligro concreto"13, "un peligro que ex ante es objetivamente idóneo para lesionar un interés legítimo propio o ajeno" ${ }^{4}$. Esta idea se encuentra presente en nuestra legislación, pues al exigirse la necesidad racional del medio empleado para defenderse, se indica claramente que es para "impedir" o "repeler" una ofensa (art. $10 \mathrm{~N}^{\circ} 4 \mathrm{CP}$ ).

\section{a) Actualidad de la agresión}

La doctrina está conteste en que un ataque inminente es una agresión actual, entendiendo que ataque inminente no es precisamente el que se está produciendo, sino aquel cuya realización es próxima. Esto sucede porque parece absurdo que el ordenamiento jurídico autorice a una persona a defenderse sólo cuando ya se ha iniciado el ataque. La persona no tiene que esperar a que el ataque se inicie para ejercer su acción defensiva ${ }^{15}$. Para Roxin ${ }^{16}$ la agresión ilegítima actual es: a) aquella que se está produciendo, b) La agresión inmediatamente anterior: caso en el cual se asimila a la fase final de los actos preparatorios, fase que es inmediatamente anterior a la tentativa, y c) La agresión incesante. Zaffaroni incluso va más allá, considera que los límites temporales de la acción defensiva se extienden "desde que surge una amenaza inmediata al bien jurídico hasta que ha cesado la actividad lesiva o la posibilidad de retrotraer o neutralizar sus efectos" 17 .

En la doctrina y jurisprudencia nacionales se entiende que agresión actual no es sólo la que se está produciendo, sino también la inminente, la que definen como "aquella que es lógicamente previsible" 18 , no siendo necesario que alcance el grado de tentativa. Basta con que no se haya "agotado" la lesión al bien jurídico. De donde se deduce que no se

${ }^{12}$ Luzón Peña, ob. cit., p. 35. En el mismo sentido en Chile, Garrido Montt, ob. cit., p. 168. Cury, ob. cit., p. 273, Politoff-Ortiz, ob. cit., p. 129.

13 Cobo Del Rosal, Vives Antón. Derecho Penal. Parte General, $4^{a}$ edición. Conforme al Código Penal de 1996, Tirant Lo Blanch, Valencia, 1996, pp. 467-468.

${ }^{14}$ Baldó Lavilla, F. ob. cit., p. 264.

15 En esta postura Mir Puig, S. Derecho Penal. Parte General (Fundamentos y Teoría del Delito), PPU.

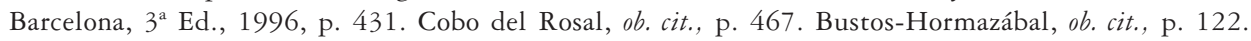
Larrauri-Verona, ob. cit., p. 33.

${ }^{16}$ Roxin, C. ob. cit., pp. 618, 619, 621.

17 Zaffaroni, E.R. Derecho Penal. Parte General, Ediar, Buenos Aires, 2a edición, 2002, p. 623.

18 Politoff-S. Ortiz, L. ob. cit., p. 130. 
admitiría como actual la agresión que ya ha cesado ${ }^{19}$. Como ha dicho la Corte Suprema: "es natural que todo hombre pueda amparar su persona de muerte cuando alguno lo desea matar, y no ha de esperar que el otro lo hiera primeramente, porque podría acaecer que por el primer golpe que aquel diese pudiese morir el acometido y después no se pudiere amparar" (ley No 2, tít. 8, Partida VII)" (considerando 6)" 20.

La asunción de una u otra interpretación es importante si lo que se busca es amparar la acción defensiva de la mujer homicida en contexto de VIF. No hay problema cuando la agresión se está produciendo, y consiste en un acometimiento físico. No obstante, cabe duda respecto de agresiones incesantes ( si la situación o contexto de malos tratos habituales pueden ser considerados como tales) o cuando la agresión es inminente (¿una amenaza de agresión puede ser presupuesto de una acción defensiva?) o en caso de "agresión inmediatamente anterior", esto es, la que ya ha cesado (la mujer que acaba de ser golpeada y reacciona violentamente contra su marido). Examinemos estas posibilidades.

a.1.) Agresión inminente: Agresión inminente es la que representa un peligro próximo o concreto para el bien jurídico protegido, teniendo su asidero legal en el art. $10 \mathrm{~N}^{\circ} 4 \mathrm{CP}$ (para impedir o repeler un ataque. La jurisprudencia nacional por regla general ha sido menos restrictiva que la comparada a este respecto ${ }^{21}$, y tiende a no restringir la agresión ilegítima a un acometimiento físico que se esté produciendo. Así por ejemplo, la Corte Suprema, en sentencia de 22-05-1968, acogió la legítima defensa de una mujer víctima de malos tratos, que había sido agredida por el marido de obra y de palabra, durante un juego de cartas con un amigo. El hombre la persiguió para golpearla porque "no sabía jugar". La mujer en su huida, desesperada, cogió un cuchillo con el que le causó la muerte ${ }^{22}$. Así también en sentencia de 28-12-2000²3 acogió la legítima defensa y la inminencia de la agresión considerando también el contexto de violencia intrafamiliar que había vivido la procesada: "La violenta agresión de Augusto Pinochet Hiriart a María Verónica Molina Carrasco se realizó el día viernes 31 de julio de 1992 a causa de la negativa de esta última a entregarle un cheque en blanco para pagar las deudas de aquél... quien arremetió físicamente con anterioridad en un breve espacio de tiempo, y que ingresó a la morada de la procesada sin su autorización, y que se negó a retirarse cuando fue conminado a hacerlo en la segunda oportunidad... [...] para que surja el derecho de defenderse no basta con las amenazas [...] pero tampoco quiere decir esto que hayamos de esperar la realización del hecho que viene sobre nosotros, para repelerlo y remediarlo enseguida[...]. Basta para autorizar el ejercicio de este derecho de que hablamos, que

\footnotetext{
${ }^{19}$ En este mismo sentido se manifiestan Garrido Montt, 2005, pp. 170-171 y Cury, 2005, p. 373.

20 SCS de 28-12-2000, fallo sobre Recurso de casación en el Fondo, Rol 1282-00, Gaceta No 246. Disponible también en Internet (www.poderjudicial.cl)

${ }^{21}$ La jurisprudencia del Tribunal Supremo español, por ejemplo, tiende a restringir la agresión ilegítima a los casos de acometimiento físico. Véase Larrauri, E.-Verona, D. ob. cit., p. 34, Luzón Peña, D.M. ob. cit., p. 131.

${ }^{22}$ Revista de Derecho y Jurisprudencia, Tomo LXV, No 3, 1968, secc. Cuarta, p. 107

${ }^{23}$ Sentencia Corte Suprema de 28-12-2000, fallo sobre Recurso de casación en el Fondo, Rol 1282-00.
} 
sea inminente la acción, que de hecho se nos amenace, que haya en realidad tentativa contra nosotros" 24 .

Cuando existen testigos de un acometimiento físico in actum, no suele negarse la exención de responsabilidad por legítima defensa. Así, por ejemplo, la Corte de Apelaciones de Valparaíso en sentencia de 27-03-2006 25 absolvió a una mujer maltratada por haber dado muerte a su conviviente drogadicto y alcohólico, el que la agredió con golpes de mano y le causó cortes leves con un cuchillo ${ }^{26}$. Mucho más restrictivos han sido los Tribunales Orales en lo Penal. Así, por ejemplo, el TOP de San Antonio, en sentencia de 22-07-2008, desestimó la legítima defensa en el caso de una mujer de la tercera edad, que tras años de maltrato, mató a su marido en un contexto de agresión, a nuestro juicio, inminente. Concretamente la mujer disparó desde el interior de la casa, a través de una ventana, a su marido que amenazándola con golpearla, pateaba la puerta de entrada que se encontraba trabada con un sillón, puesto por la mujer para impedir que éste entrara. El tribunal señaló: “[...] que no existe agresión ilegítima, pues: no se ha establecido que el occiso haya agredido a la acusada en los instantes previos a suscitarse los hechos. Si bien la defensa intentó acreditar lesiones que supuestamente avalarían esa agresión no fue posible concluir que correspondieran al obrar de la víctima el día de los hechos, toda vez que ningún testigo u otro medio de prueba dio cuenta de la misma, no existiendo certeza del momento en que las mismas ocurrieron" 27.

${ }^{24}$ Considerando cuarto. Lo subrayado es nuestro. Pareciera ser que en este caso la agresión ilegítima se encontraría en el hecho de ingresar a la morada sin autorización. La Corte de Apelaciones de Santiago, que en esta misma causa había condenado a la mujer por lesiones dijo que no hubo legítima defensa "por no concurrir la exigencia de haber precedido una agresión ilegítima actual, esto es una que se hubiere desarrollado inmediatamente antes de los actos de defensa", ya que "todos (los testigos) se refirieron a una golpiza que tuvo lugar el día anterior”. Sentencia Corte de Apelaciones de Santiago, de 10-03-2000, Rol No 29.784-98. Dictada por los Ministros Sres: Haroldo Brito, Raimundo Díaz, Domingo Hernández. En Gaceta No 246.

${ }^{25}$ Sentencia Corte de Apelaciones de Valparaíso de 27-03-2006, Rol No 7356-04. Recurso n 7356/2004, Sentencia $\mathrm{N}^{\circ} 10736$.

${ }^{26}$ Dijo la Corte de Apelaciones de Valparaíso: "No ha de esperarse que el otro lo hiera primeramente, pues podría acaecer que por el primer golpe que aquel diese pudiere morir el acometido y después no se pudiera amparar”. Así también la Corte de Apelaciones de Rancagua, en sentencia de 30-06-1970. acogió la legítima defensa en el caso de un hijo condenado en primera instancia por el parricidio de su padre, brutal maltratador, señalando: "No es necesario que el atentado contra la persona se consume para que tenga derecho a defenderse, pues basta que tema un peligro inminente para que haga uso del medio que se juzgue más apropiado para evitarlo”. Rev. de Derecho y Jurisprudencia, Tomo 67, 1970, secc. 4 pp. 291-295. Cit por Campos, M.-Navea, K.-Olivos, F. Uxoricidio: una reacción de la mujer frente a la violencia intrafamiliar. Memoria para optar al grado de licenciado en Ciencias Jurídicas y Sociales, dirig. por Loreley Friedman V., Fac. Derecho, Universidad de Chile, 2004, pp. 100-101

${ }^{27}$ Sentencia TOP de San Antonio de 22-07-2008, RIT 49-2008, RUC 0700509932-8. En igual sentido Sentencia TOP de Castro de 5-04-2006, RIT 4-2006, RUC No 0500142125-7: "Reconoce la existencia de episodios de violencia intrafamiliar, pero estima que no ha logrado establecerse con certeza, ya que sólo se sustenta en rumores, y además, la acusada mantenía una relación sentimental paralela con M.C., por lo que tenía otra contención emocional". Citada en "La Ley N N 20.066: determinación de la violencia psicológica, la procedencia de comisión por omisión y los presupuestos de admisibilidad de la legítima defensa”. Minuta No 2. Departamento de Estudios Defensoría Nacional. Santiago de Chile, noviembre de 2009, p. 7. 
De esta sentencia se puede observar que uno de los principales problemas se ocasiona con la prueba de la agresión, y en esto, son los Tribunales superiores los que dan la pauta. Así, la Corte Suprema en un caso indicó que la víctima de violencia intrafamiliar "señala que desde el inicio de su relación conyugal, fue sometida a todo tipo de apremios físicos y síquicos, tales como golpes en la cara, en el cuerpo, amenazas y requerimientos de cumplimiento de débito conyugal durante períodos en que ella estuvo enferma, incluso con riesgo de pérdidas de los niños que esperaba. No obstante lo reiterado de esta situación, jamás hizo denuncia alguna; nunca se lo comunicó a sus padres ni se quejó ante sus amigas" ${ }^{28}$. Las Cortes de Apelaciones reproducen estos mismos razonamientos: "la violencia intrafamiliar que la acusada habría sufrido... solo permite presumir que hubo discusiones y agresiones mutuas y quizás golpes que la mujer haya recibido, pero de manera alguna se ha probado una violencia de la gravedad y persistencia que permita suponer la obcecación ... y mucho menos si no se... probó, que la acusada haya intentado otras formas de solución del problema, que no la llevaran al crimen como la denuncia de los abusos ante las autoridades, o el abandono del hogar común" 29.

Otro problema es que la inminencia de la agresión para configurar la actualidad es sinónimo de agresión física casi instantánea. En situación de VIF la amenaza de agresión, no es considerada agresión inminente, olvidando que en este contexto las amenazas proferidas por el agresor tienen una especial significación en términos de hacer peligrar la vida e integridad de la mujer. Es así que cuando el marido le señala a su cónyuge "ya veremos a mi regreso", la mujer sabe exactamente el significado y contenido de esa frase, significa “ya te golpearé a mi regreso". Por tanto, existe a lo menos una violación a la libertad y la seguridad individual de la mujer ${ }^{30}$. Da la impresión que el problema reside en cómo configuramos la inminencia, si se exige un espacio de tiempo medible con criterios cronológicos o con otros. En los pocos casos en los que se acoge la inminencia es cuando la agresión "se viene en el momento de la defensa". Sin embargo, no se considera igual cuando el marido amenaza, se va y vuelve tres horas después. Si la mujer lo espera armada con un palo a fin de prevenir un ataque lógicamente previsible en el contexto que vive y le asesta un golpe y lo mata, la condena por homicidio es segura. En este sentido, se estima que el criterio para definir la inminencia no ha de ser cronológico, sino psicológico en el entendido de otorgar preeminencia a la subsistencia de la voluntad delictiva en el agresor, cuando regresa a la casa de su víctima después de amenazar, hecho que pudiera comprobarse demostrando la permanencia de dicha conducta en el tiempo.

a.2) Agresión incesante: La legítima defensa puede apreciarse también cuando la agresión es incesante, lo que suele suceder en los delitos permanentes, p. ej. la víctima de una detención ilegal que se defiende de su captor mientras dura la privación de

${ }^{28}$ Sentencia Corte Suprema de 28-12-2000, fallo sobre Recurso de casación en el Fondo, Rol 1282-00, Rol 1282-00.

29 Sentencia Corte de Apelaciones de Rancagua de 22-11-2004. Rol 221196.

${ }^{30}$ Larrauri, E.-Verona, D., ob. cit. pp. 36 y 38. 
libertad $^{31}$. Si el secuestrado puede defenderse legítimamente de su agresor, ¿por qué no puede hacerlo la víctima de malos tratos y agresiones habituales? La escasa jurisprudencia en nuestro país parece quedarse en el umbral y no tocar el tema. En las sentencias ya mencionadas, cuando se ha acogido la legítima defensa ha sido para "reforzar" una agresión in actum o inmediata. En nuestra opinión, la agresión ilegítima en contexto de VIF siempre es actual (aun cuando el bien jurídico amenazado no sea la vida o la integridad física), porque de forma permanente se está lesionando la libertad y la seguridad de la mujer y los hijos ${ }^{32}$. Por tanto, el delito de maltrato habitual a que se refiere el art. 14 de la Ley $\mathrm{N}^{\circ}$ 20.066, es un delito permanente, y no habitual, pues en el delito habitual, p. ej. el ejercicio ilegal de profesión, una sola actividad aislada es atípica, siendo la "habitualidad", esto es, la reiteración de la conducta en el tiempo, lo que configura el tipo penal como tal. En cambio, en los malos tratos habituales, una sola acción aislada puede ser atípica o no serlo (vr.gr. lesiones, coacciones, amenazas, vías de hecho, etc.). La Ley $\mathrm{N}^{\circ} 20.066$ en ningún caso dice que los malos tratos habituales son solo psicológicos. Los delitos permanentes se caracterizan por la creación de un estado antijurídico, de lesión o puesta en peligro para el bien jurídico, que subsiste a la acción u omisión inicial, por lo que el sujeto sigue cometiendo ininterrumpidamente el delito. Esto es lo que ocurre en el delito del art. 14 de la Ley $\mathrm{N}^{\circ}$ 20.066, pues la reiteración de actos conectados espacio-temporalmente entre sí crea un estado antijurídico de violencia inminente en el hogar, en el que la vida, la integridad, la libertad y la seguridad de la mujer y sus hijos se ven constantemente en peligro. Por ende, a su respecto cabría apreciar la existencia de una agresión incesante, una agresión latente, capaz de configurar el requisito de actualidad en la legítima defensa.

a.3) Agresión que ya ha cesado: Es frecuente que la mujer para defenderse espere que la agresión se interrumpa o cese, y esto porque, como se ha dicho, en general la mujer por su inferioridad física no tiene reales posibilidades de defensa con éxito mientras la agresión se esté produciendo. El cese de la agresión llevaría a considerar la inexistencia del requisito de "agresión ilegítima", o bien un "exceso extensivo en la defensa" como indica la doctrina mayoritaria ${ }^{33}$ y reiteradamente la jurisprudencia española ${ }^{34}$.

${ }^{31}$ Bustos, J.-Hormazábal, H. ob. cit., p. 124. En el mismo sentido Roxin, C., ob. cit., p. 621, Garrido Montt, M. ob. cit., p. 171.

32 En esta opinión seguimos a Elena Larrauri y Daniel Verona, ob. cit., p. 38.

${ }^{3}$ Silva Sánchez, J. M., Baldó Lavilla, F., Corcoy Bidasolo, M. Casos de jurisprudencia penal con comentarios doctrinales, Bosch, Barcelona, 1997, p. 252, Larrauri, E.-Verona, D. ob. cit., p. 39. En doctrina nacional, por todos, Cury, E. ob. cit., p. 373.

${ }^{34}$ Así, por ejemplo, la Sentencia del Tribunal Supremo de 2-10-1981 consideró un exceso en la defensa en el siguiente caso: "Francisco, profiriendo constantes amenazas contra la mujer y los demás componentes de la familia albergados en el garaje, consiguió finalmente tras varios golpes, que la puerta metálica de acceso cediera [...]. Una vez dentro, enarbolando un martillo en cada mano se dirigió a la procesada al tiempo que decía "los mato a todos"...; la procesada (lógicamente prevenida ante la evidente conducta agresiva del que así forzó la entrada en la vivienda), con una escopeta de dos cañones y a una distancia de dos metros, le disparó con ánimo homicida dos tiros que alcanzaron a Francisco en el pecho y al ver que éste se movió dirigiéndose a las escaleras que dan acceso a la vivienda, creyendo que no se encontraba herido, dado que en aquel momento no existía luz en la habitación y pensara que pretendía subir para coger una segunda escopeta 
La jurisprudencia en nuestro país, en caso de una agresión que ya ha cesado, ha sido proclive a apreciar la concurrencia de una causal de inexigibilidad, el miedo insuperable en la mujer, pero no la legítima defensa. Nos parece interesente destacar en este punto la opinión de Zaffaroni, quien considera que cabe apreciar la legítima defensa en casos en que el ataque ya haya cesado pero la lesión al bien jurídico persista en el tiempo. Y pone como ejemplo, que defiende legítimamente su patrimonio el propietario de un vehículo que lo recupera directamente de manos del delincuente dos días después de que se lo han robado 35 .

\section{b) Necesidad racional del medio empleado}

Se suele argumentar que la mujer pudo acudir a otras vías de solución, como llamar a carabineros, o se llega a entender la "racionalidad" de manera matemática. Hay que tener presente que la necesidad de defensa exige que la agresión ilegítima ponga en peligro a la persona o derechos propios o ajenos (necesidad en abstracto), y que esta necesidad de defensa "en abstracto" supone un límite en los medios empleados, es decir, necesidad racional del medio (necesidad en concreto) ${ }^{36}$. Partiendo de esta base, reflexionemos sobre los problemas antes señalados:

b.1) ¿Deber de huir?, ¿buscar otra solución en ese momento? ${ }^{37}$ : que la mujer tenga que huir en lugar de atacar a su agresor, como irse a casa de la vecina, o de parientes, no es un requisito que la ley imponga para apreciar la legítima defensa. Como señala la doctrina española: "no es exigible al agredido que evite la agresión huyendo. Solo en casos que ésta provenga de un niño, de un enfermo mental, etc., se debe evitar la agresión por un medio distinto de la defensa" 38 , "incluso cuando la huida es posible, cabrá recurrir a otros medios defensivos, más nocivos para el agresor, pues el derecho no tiene por qué ceder ante el ataque injusto" 39 . Nuestra doctrina se manifiesta en similar sentido. "La huida vergonzosa, no puede exigirse al que se encuentra en legítima defensa, pues ante el injusto de la agresión nadie está obligado a ceder" ${ }^{\prime \prime}$.

En cuanto a buscar otras vías de solución, tales como denunciar a carabineros, acudir al tribunal, etc. cabe indicar que hasta ahora ni la autoridad administrativa ni la judicial han demostrado eficacia en la prevención de delitos cometidos en contra de mujeres por parte de sus cónyuges o convivientes ${ }^{41}$. Por otra parte, el abandono de hogar

existente en aquella (en la vivienda), le siguió golpeando con una azada en la región occipital, causándole heridas que le ocasionaron junto a las producidas por los dos disparos, la muerte casi instantánea..."Citada en Baldó Lavilla, ob. cit., p. 271. En el mismo sentido Sentencia Tribunal Supremo 25-04-1979. Citada en Silva Sánchez, J.M., Baldo Lavilla, Corcoy Bidasolo, ob. cit., p. 231.

35 Zaffaroni, ob. cit., p. 623.

${ }^{36}$ Bustos,J.-Hormazábal, H. ob. cit., pp. 128-129. También Cobo del Rosal-Vives Antón, ob. cit., p. 469.

37 En este punto nos sumamos a lo dicho por Elena Larrauri y Daniel Verona en la obra ya citada.

38 Bacigalupo, E. Derecho Penal. Parte General. Hammurabi, Buenos Aires, 2a. Ed. 1999, p. 369.

39 Cobo del Rosal-Vives Antón, ob. cit., p. 470.

${ }^{40}$ Cury, E. ob. cit., p. 375. En el mismo sentido, Garrido Montt, M. ob. cit., p. 173.

${ }^{41}$ Rioseco, L, ob. cit., p. 709. 
puede traer consecuencias nefastas de persecución y agresividad. La policía puede no llegar a tiempo, el vecino o los parientes pueden no querer o temer involucrarse con el agresor $^{42}$. Por tanto, el argumento de que la mujer pudo buscar otras vías de solución más parece moverse en el plano de lo teórico que de lo real. En este sentido, la Corte Suprema ha sido clara: "La legítima defensa propia autoriza para obrar y contraatacar al propio agredido y la esperanza de obtener la ayuda de un tercero... no es un medio idóneo para repeler la agresión actual y positiva" 43 .

b.2.) La racionalidad del medio empleado: la mujer agredida no tiene más alternativa que acudir a medios que son esencialmente gravosos para poder tener una defensa exitosa. Por esto es que "racionalidad" del medio no debe ser interpretado como "proporcionalidad", situación que suele presentarse en la jurisprudencia comparada ${ }^{44}$, pues una cosa es la relación entre la naturaleza de la agresión y la defensa ("racionalidad"), y otra cosa es la proporción entre el daño que hubiera causado la agresión y el daño causado por la defensa ("proporcionalidad") ${ }^{45}$. La jurisprudencia nacional parece haber captado esta distinción. La Corte Suprema ha dicho que en el medio empleado en la legítima defensa “...será racional cuando la sana razón lo justifique atendida la calidad de la agresión, las condiciones físicas del agresor y la naturaleza del bien jurídico que se trata de proteger"... "Si la cónyuge era atacada por un fornido boxeador. Agresivo, violento, celoso, y en estado de embriaguez del cual huyó para evitar mayores castigos y mientras era perseguida tomó un cuchillo para defenderse de la agresión [.... Parece evidente que usó el medio que en esa oportunidad tenía al alcance para repeler la agresión que derechamente amagaba su integridad personal y concurre consiguientemente, el requisito de la necesidad racional del medio empleado..." 46.

Por ende, parece claro que la necesidad racional del medio empleado, debe apreciarse ex ante conforme a la situación personal y circunstancias en que se encontraba el defensor al momento de defenderse, ponderando entre otros la perturbación psicológica del agredido y la posibilidad de elegir razonablemente el medio más adecuado ${ }^{47}$. Por

\footnotetext{
42 Ibidem, p. 72.

${ }^{43}$ Revista de Derecho y Jurisprudencia, Tomo LXV, No 3, 1968, secc. Cuarta, p. 107. Cit por CamposNavea-Olivos, ob. cit., pp. 100-101.

${ }^{44}$ Sentencias Tribunal Supremo de 20-3-1980, 2-10-1981, 18-6-1985, 22-6-1985, 132-4-1987. Cit. por Bustos, J.-Hormazábal, H. ob. cit., p. 129.

45 Bacigalupo, E. ob. cit., p. 369. En similar sentido la doctrina nacional para quienes "la necesidad racional del medio empleado dependerá de la naturaleza del ataque, en el sentido que la reacción defensiva guarde una relación de proporcionalidad con el ataque de que se es víctima, de la naturaleza del bien jurídico, en el sentido de que exista cierta racionalidad al defender un determinado bien jurídico sacrificando otro...". Bullemore, V. y otro, ob. cit., p. 59. En contra de esta postura, Politoff, S.-Ortiz, L. ob. cit., p. 131, para quienes "la racionalidad del medio empleado en impedir o repeler la agresión no está condicionada a la naturaleza del bien atacado o la forma de agresión, pero debe respetar los límites de proporcionalidad y racionalidad".

46 Sentencia Corte Suprema de 22-05-1968. Revista de Derecho y Jurisprudencia, Tomo LXV, No 3 , 1968, secc. Cuarta, p. 107.

${ }^{47}$ Puente Segura, L. Circunstancias eximentes, atenuantes y agravantes de la responsabilidad criminal, Colex, Madrid, 1997, p. 179.
} 
otra parte, "si en el contexto concreto, a disposición del defensor sólo existe un medio objetivamente idóneo para impedir o repeler la agresión, éste tendrá la consideración de medio racionalmente necesario, por más que origine daños en la esfera de intereses del agresor mucho mayores que los que la defensa pretende evitar" ${ }^{48}$. Así lo ha entendido la Corte Suprema (S. de 28-12-2000) ${ }^{49}$. Luego, parece adecuado que el parámetro para medir la racionalidad de la respuesta en situaciones de VIF no ha de hacerse sobre la base del "hombre medio" sino de la "mujer media en ese contexto" 50.

c) El elemento subjetivo en la legítima defensa: Muchas veces, especialmente en la jurisprudencia comparada, se desestima la legítima defensa porque la mujer no tiene "voluntad de defensa" sino "voluntad de venganza", confundiendo así el elemento subjetivo de la causa de justificación con el móvil. Desde luego que es preciso exigir la intención de defenderse, ya que el que actúa en defensa, actúa dolosamente ${ }^{51}$. Pero esto nada tiene que ver con el móvil, pues como indica la doctrina mayoritaria "los motivos que guíen al sujeto para nada afectan la licitud de la defensa" ${ }^{52}$. Incluso más, "el actuar en defensa no es impedimento de que se haga además, con estados anímicos vindicativos o de naturaleza análoga" 53 . Por ende, en el caso de la mujer víctima de VIF, la presencia de móviles adicionales, tales como la venganza o el odio, no eliminan el conocimiento de la situación de agresión ni tampoco la intención de defenderse ${ }^{54}$.

\section{II.2. Estado de necesidad defensivo}

Una mujer, sometida a malos tratos físicos y psicológicos constantes por parte de su pareja durante años, ha salido de compras sin avisar. El sujeto, excesivamente celoso, le recrimina, y tras una discusión sale a beber con los amigos, no sin antes advertir a la mujer, y en presencia del hijo mayor: "ya verás cuando regrese". La mujer y el hijo saben que eso significa golpiza segura, tras años de malos tratos han aprendido a prever las consecuencias de esas advertencias (o amenazas), conocen el contenido exacto de esas

${ }^{48}$ Baldó Lavilla, ob. cit., p. 310.

49 “... la circunstancia que según los propios dichos del ofendido éste sea experto en artes marciales y por su preparación militar conozca diversas conductas y formas de combate, hacen racional el medio empleado por la acusada, siendo al momento el único medio a su alcance, y por la propia declaración de la misma, en relación a no producir un daño excesivo, apuntando no hacia el cuerpo del ofendido, sino derechamente hacia las extremidades inferiores del mismo". Sentencia Corte Suprema de 28-12-2000, fallo sobre Recurso de casación en el Fondo, Rol 1282-00.

${ }^{50}$ En ese sentido, Larrauri, E.-Verona, D. ob. cit., p. 49.

${ }^{51}$ En este sentido, Bustos, J.-Hormazábal, H. ob. cit., p. 133, Bacigalupo, E. ob. cit., p. 371.

52 Luzón Peña, D. ob. cit., p. 44, Silva Sánchez-Baldó Lavilla, Corcoy Bidasolo, ob. cit., p. 258. En nuestro país, Politoff, S.-Ortiz, L. ob. cit.: "sólo es necesario el conocimiento de la situación de agresión, exigencia subjetiva que puede coexistir con otros propósitos, que no sean los de enfrentar una situación de agresión, sin que ello obste a la aceptación de la justificante en su forma completa” (p. 131).

53 Garrido Montt, M. ob. cit., p. 175.

54 En esta postura que se comparte y defiende apoyando con doctrina penal chilena, Larrauri, E.Verona, D. ob. cit., p. 52. 
frases $^{55}$. Deciden esperar al agresor armados con un palo. Al ingresar éste en la vivienda, tres horas después, borracho, la mujer se abalanza sobre él y lo golpea en la cabeza, el sujeto se vuelve hacia la mujer para pegarle y el hijo asesta un segundo golpe en la cabeza con otro palo que tiene a su vez entre las manos. Ambos golpes le ocasionan la muerte por TEC.

Considerando todas las dificultades que se han evidenciado con anterioridad parece complicado acreditar el haber obrado en legítima defensa para la mujer, con mayor razón en el caso del hijo, quienes probablemente serán condenados como coautores de parricidio o de homicidio calificado, con alguna atenuante. Tampoco parece plausible alegar miedo insuperable, ya que como veremos, existen serias dificultades de prueba para darlo por configurado. No obstante, puede eximirse de responsabilidad penal a ambos por la vía de una causal de justificación supralegal: el estado de necesidad defensivo ${ }^{56}$, que si bien suele identificarse en sus requisitos con la legítima defensa ${ }^{57}$, tiene con ella algunas diferencias importantes, especialmente a la luz de la doctrina penal alemana (Roxin).

\section{Fundamento y Concepto}

El fundamento del estado de necesidad justificante es "el interés preponderante" del bien jurídico salvado por sobre el afectado. Dentro del mismo se distingue entre estado de necesidad agresivo y defensivo. En el estado de necesidad agresivo, el sujeto actuante ataca el bien jurídico de otra persona "no implicada" para salvarse o salvar a otro de un peligro $^{58}$. Es decir, el sujeto afectado no es quien origina la fuente del peligro y tolera la agresión por el deber de solidaridad que el ordenamiento jurídico impone a todas las personas. En el estado de necesidad defensivo, el sujeto se defiende frente a un peligro que es originado por el titular del bien jurídico afectado ${ }^{59}$, siendo la legítima defensa preventiva una subespecie del mismo, en virtud de la cual "se impide una agresión sólo en fase de preparación con medidas preventivas, porque posteriormente ya no sería posible (o sólo lo sería con mucha mayor dificultad) una defensa" ${ }^{60}$. Ahora bien, la fuente de peligro puede provenir de cosas, animales, comportamientos humanos (que no configuran agresión ilegítima) ${ }^{61}$. En este último caso existen restricciones, sin embargo, se permite matar o lesionar cuando lo que está en peligro es la propia vida o la integridad física, pues "nadie está obligado a soportar peligros provenientes de fuentes ajenas, sino porque

55 Sobre este punto, véase: Larrauri-Verona, ob. cit., pp. 23 y ss.

56 Sobre este punto, véase Chocano Rodríguez, R. "Situaciones de necesidad de las que derivan causas de justificación: estado de necesidad agresivo y defensivo", disponible en http://www.unifr.ch/ddp1/derechopenal/anuario/an_2003_12.pdf (fecha consulta: 22-03-2010).

57 Así sucede en la legislación española, art. 20.4 del CP español.

${ }^{58}$ Roxin, C. ob. cit., p. 705.

59 Chocano, R. ob. cit., p. 3.

${ }^{60}$ Roxin, C. ob. cit., p. 706.

${ }^{61}$ Chocano, R. ob. cit., p. 7. 
a nadie se le puede imponer que tolere el peligro de muerte o lesión" ${ }^{62}$. Precisamente este es el caso que nos ocupa: el maltratador en situación de violencia intrafamiliar que al final resulta muerto por su pareja (maltratada) o incluso por sus mismos hijos, es quien origina, con su comportamiento, la fuente de peligro que finalmente desemboca en la conducta delictiva.

\section{Requisitos}

Requisito básico del estado de necesidad es la existencia de una situación de necesidad, en la que deberá sacrificarse un bien jurídico para salvar otro, y que a su vez debe cumplir con dos condiciones: a) que no exista una vía legítima a la que pueda recurrirse y b) que no exista una vía menos lesiva ${ }^{63}$. Nos encontramos con los mismos problemas anotados respecto de la legítima defensa, y objetables de la misma forma. Respecto del primer requisito, llamar a la policía, abandonar el hogar, llamar al vecino, son vías legítimas pero improcedentes de ser exigidas cuando carecen de posibilidades reales de impedir el mal que se trataba de evitar. Respecto de la utilización de la vía menos lesiva, se concuerda con Larrauri y Verona ${ }^{64}$, en orden a considerar que el uso de un medio que no era el menos lesivo en el caso concreto, no es suficiente para eliminar la situación de necesidad, pues el conflicto existe de todas maneras.

Ahora bien, para que exista la situación de necesidad, o el mal o peligro que se trata de evitar debe ser inminente. $\mathrm{Y}$ en este punto es donde se encuentra la diferencia con la legítima defensa, ya que la inminencia del mal o peligro que se trata de evitar en el estado de necesidad defensivo puede prolongarse en el tiempo, lo que no sucede con la agresión ilegítima de la legítima defensa, salvo casos excepcionales de agresión permanente, p.ej. secuestro. Luego, cuando se trata de evitar a modo preventivo una "agresión que aún no es actual”65, nos encontramos ante una legítima defensa incompleta, en su carácter de legítima defensa preventiva, que si bien no permite justificar completamente el comportamiento por esta vía, eso no significa que no pueda ser justificado vía estado de necesidad defensivo, "pues en los casos en que, si la agresión llegara a la fase de agresión actual, ya no se le podría hacer frente o sólo sería posible con un alto riesgo de desenlace mortal para el agresor, no sería razonable prohibir totalmente una medida preventiva anterior y más considerada" 66 .

Incluso más, como indica Roxin, debe apreciarse el estado de necesidad justificante en aquellos casos en que alguien no está seguro de si concurre una causa de justificación "pero esperar más produce el peligro de que sea demasiado tarde para evitar el daño" 67 , esto es, en casos de error. Esto porque si bien conforme al §35 Stgb sólo cabría apreciar

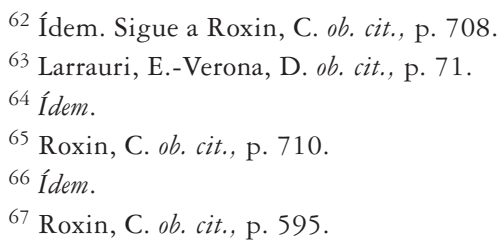


una exculpación frente al "que se siente amenazado y empuña la navaja o revólver", esta situación "no puede variar si después se demuestra que en realidad existía una acción peligrosa, que habría otorgado a la víctima un derecho de defensa si la víctima no hubiera actuado sobre la base de una sospecha incierta para al mismo. Pero en su resultado tal exculpación equivale en este caso a una justificación, dado que el agresor antijurídico no puede reivindicar un derecho de defensa legítima"68.

Luego, en el estado de necesidad defensivo la situación de necesidad comprende ${ }^{69}$ : a) el peligro inminente, b) los peligros continuados, c) los peligros que se reproducen. Respecto del peligro inminente, en nuestro medio jurídico, la legítima defensa alcanza a cubrir esta situación, bajo la forma de agresión ilegítima inminente. Respecto de los peligros continuados ("dauergegfhar) se estima que es la figura que cubre la situación como la descrita en nuestro ejemplo inicial, la idea de un peligro latente, que puede producirse o concretarse en cualquier momento, pero no se sabe a ciencia cierta en qué momento se convertirá en agresión. Es lo que al examinar la legítima defensa hemos denominado "agresión incesante" y que pudiera no tener cabida en la jurisprudencia nacional en casos de malos tratos familiares. Respecto de los peligros que se reproducen, son peligros no siempre latentes pero que pueden reproducirse en el tiempo.

En ambos casos, como apunta Larrauri, "el fundamento del estado de necesidad estriba en que a pesar de que el peligro no se materialice directamente, el transcurso del tiempo no va a aportar una solución menos gravosa"70. Por eso es que "la necesidad de defensa del bien jurídico conjuntamente con el convencimiento de que las posibilidades de defensa no van a mejorar es lo que lleva a que se acepte el estado de necesidad a pesar de que el peligro no sea inminente" 71 .

En cuanto a la ponderación de intereses en conflicto en el estado de necesidad defensivo, señalan algunas autoras que es posible apreciar la defensa justificante "aunque el interés jurídicamente protegido no sea sustancialmente preponderante" 72 . Y por eso, cuando el bien amenazado es la vida o la salud, es posible defenderse lesionando, y si es necesario "incluso matando al causante del peligro, aunque el interés propio en la integridad y la vida no sea sustancialmente preponderante o no sea en absoluto preponderante o incluso sea inferior al interés de la víctima en los mismos bienes jurídicos"73. Es decir, en esta causal supralegal de justificación del estado de necesidad defensivo hay que acudir a un criterio de ponderación de intereses distinto al habitual (en donde el bien sacrificado debe ser de menor valor) y, por tanto, en el estado de necesidad defensivo "el daño producido puede ser mayor que el evitado y únicamente no puede ser desproporcionado con el peligro que amenaza" 74 .

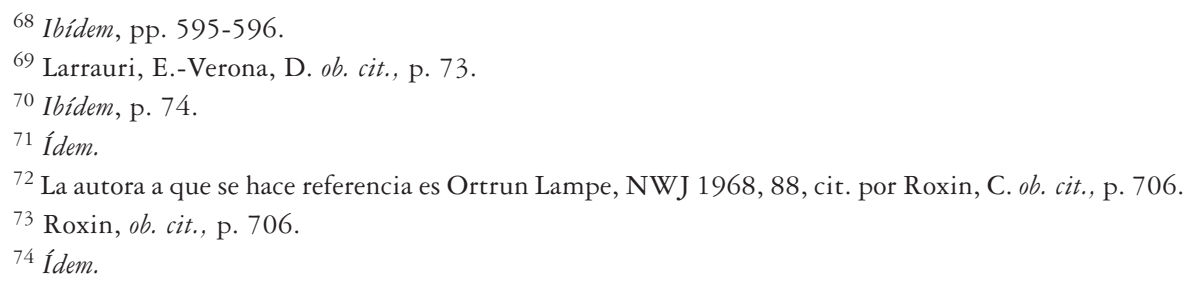


En contra, Roxin resuelve esta situación de otra manera, indicando que "muchas veces el bien jurídico protegido no sea sustancialmente más valioso que el dañado, no excluye que el interés protegido sea sustancialmente preponderante sobre el dañado" 75 . Es decir, un bien jurídico más valioso según su rango puede ceder ante un bien jurídico menos valioso cuando el interés en proteger este último sea sustancialmente preponderante frente al interés en que el otro quede intacto" 76 , lo que a la perfección es aplicable al caso del ejemplo: la mujer que mata al marido cuando éste retorna a casa tras un par de horas de haberle amenazado con golpearla. El interés de la mujer en salvar su vida o integridad física frente a la amenaza del peligro creada por el agresor es un interés que por sus peculiares características es sustancialmente preponderante al interés que el que el agresor siga vivo, pues ella no sólo protege su propia vida o integridad, sino también su dignidad humana, la integridad física y salud mental de los hijos, todo lo cual se ve amenazado por el abuso de poder que entraña el comportamiento agresivo del agente.

Lo que no se comprende, y en esto se coincide plenamente con Larrauri y Verona ${ }^{77}$, es que en casos restringidos a la violencia de género Roxin sostenga lo contrario. Dice el autor: "si en un estado de necesidad defensivo alguien ve amenazada su vida y su salud, no se le podrá exigir que asuma el riesgo de sufrir la muerte o lesiones graves, por tanto, la persona en peligro, actúa justificadamente si lesiona gravemente, o en un caso extremo, incluso mata al causante del peligro" ${ }^{78}$. Pero más adelante señala: "por el contrario, en el caso de que se mate mientras duerme al padre que maltrata brutal y constantemente a su familia, hay que excluir absolutamente la justificación del $\$ 34$ (estado de necesidad) -incluso aunque sea imposible avisar a las autoridades o se haga sin resultado- pues un derecho a matar solo puede existir dentro del marco de la legítima defensa, y en el caso de estado de necesidad defensivo, puede haberlo a lo sumo en caso de un peligro similar a la agresión, agudo e inminente para la vida o la integridad. Por consiguiente, el hecho de matar al tirano familiar sólo puede a lo sumo exculparse conforme al $\S 35$ (estado de necesidad exculpante)". Con lo cual en la legislación chilena estaríamos remitiéndonos a la causal de inexigibilidad de otra conducta, probablemente el miedo insuperable.

\section{Alcance de los efectos del estado de necesidad}

El texto legal no distingue entre si el que produce el daño al otro bien jurídico es el titular del bien jurídico principal amenazado por el peligro o es un tercero extraño,

\section{5 Ídem.}

${ }^{76}$ Roxin, C. ob. cit., p. 707. De esta forma, aunque el requisito del estado de necesidad sea que el mal causado sea mayor que el que se causa para evitarlo, es posible reinterpretar el requisito desde esta perspectiva de Roxin, para lo cual, al menos en la doctrina alemana, no se precisa una nueva causal supralegal de justificación, pudiendo caber la hipótesis en el mismo $\$ 228$ BGB. Respecto del caso chileno la única posibilidad de acudir al estado de necesidad defensivo es transformándolo en una causal supralegal de justificación.

${ }^{77}$ Larrauri, E.-Verona, D. ob. cit., p. 79

${ }^{78}$ Roxin, C. ob. cit., p. 708. 
por tanto, la causa de exención alcanza a ambos. En palabras de Novoa: "cualquiera que actúe, cumple la voluntad del derecho en orden a que el bien jurídico más valioso sea salvado"79. De esta forma, el acudir al estado de necesidad defensivo como causal supralegal de justificación, no sólo puede beneficiar a la mujer víctima de malos tratos sino asimismo al hijo que coopera con ella en la muerte del maltratador.

\section{Causales de inexigibilidad de otra Conducta (Exculpación)}

Claramente, conforme a nuestro estudio, cuando la jurisprudencia nacional ha querido eximir de responsabilidad a la mujer que mata a su pareja en contexto de VIF, se inclina más por la exculpación que por la justificación, considerando que la situación de violencia intrafamiliar produce en la mujer un estado anímico que altera su voluntad, capaz de configurar el miedo insuperable o una vis compulsiva (fuerza irresistible). Con todo, su concurrencia ha sido también apreciada de manera restrictiva, y en aquellos casos en los que no se ha considerado, ha sido por falta de acreditación de la situación de violencia intrafamiliar (malos tratos persistentes) o porque existe una fuerte tendencia en los tribunales a asimilar la eximente de miedo insuperable con el trastorno mental, produciéndose así una confusión entre el contenido de las eximentes.

\section{III.1. Miedo insuperable}

\section{a) Naturaleza jurídica y Concepto}

Conforme al art. 10.9 del CP, queda exento de responsabilidad penal el que "obra... impulsado por un miedo insuperable”. La doctrina mayoritaria en nuestro país coincide en estimar que estamos ante una causal de inexigibilidad en la conducta ${ }^{80}$. En la doctrina comparada, si bien la mayor parte de los autores coincide en atribuirle el carácter de causal de exculpación por no exigibilidad ${ }^{81}$, la cuestión no es pacífica, pues otros la consideran una causal de justificación ${ }^{82}$. El miedo es un estado emotivo que debe distinguirse del simple temor, aprehensión o inquietud, pero debe alcanzar una cierta intensidad que impida al sujeto ejercer libremente su voluntad. Pero tampoco al punto de alterar por completo sus facultades psíquicas hasta privarlo de razón, aunque sea en

${ }^{79}$ Novoa Monreal, E. Curso de Derecho Penal Chileno, Parte General. Tomo I., Edit. Jurídica de Chile, 2005, p. 369.

${ }^{80}$ Cury, E. ob. cit., p. 458, Náquira Riveros citado en Politoff, S.-Ortiz, L. ob. cit., p. 147, Prambs, J. El tipo de culpabilidad en el Código Penal chileno: una visión sistemática normativa y positiva, Metropolitana, Santiago de Chile, 2005, pp. 232 y ss.

${ }^{81}$ Por todos, Mir Puig, S. ob. cit., p. 613 y Cerezo Mir, Derecho Penal. Parte General. Edit. Universidad Nacional de Educación a Distancia, Madrid, 2a. Ed. 2000, pp. 130-131. En Chile en el mismo sentido, Cury, E. ob. cit., p. 458. Politoff, S.-Ortiz, L. ob. cit., p. 148.

${ }^{82}$ Por todos, Gómez Benítez, J.M. Teoría Jurídica del delito. Derecho Penal. Parte General, Civitas, 1984, pp. 435 y ss. 
forma transitoria ${ }^{83}$. El miedo insuperable "no excluye la voluntariedad de la acción, sino que la priva de la normalidad necesaria para que pueda imputarse penalmente al sujeto", toda vez que opera frente a la amenaza de un mal que opera como coacción sobre la mente del sujeto ${ }^{84}$.

b) Requisitos del miedo insuperable

Para configurarse como causal de inculpabilidad el miedo debe reunir dos requisitos: ser insuperable y que el sujeto no tenga obligación de soportarlo. En la situación que nos convoca, nos interesa delimitar la insuperabilidad del miedo. La doctrina nacional mayoritaria estima que ella ha de regirse o medirse con el parámetro de un "hombre medio ideal" colocado ex ante en la situación del actor ${ }^{85}$, es decir, un criterio objetivo que permitiría "no exigirle al que lo sufre un comportamiento diverso, un miedo que lo presione psicológicamente, de modo que una persona normal no pueda vencerlo en las condiciones que enfrentó el afectado" 86 . Esta posición es discutible, pues en primer lugar olvida que la exigibilidad es un elemento de la culpabilidad, entendida ésta como responsabilidad del sujeto por su actuar en un contexto normal; por otro lado, se olvida que el baremo para determinar la inimputabilidad o concurrencia de un error de prohibición inevitable es de carácter personal-objetivo y, por último, que el miedo insuperable es de carácter subjetivo. En consecuencia, habría que considerar la vivencia del actor que sufrió el miedo, y no la hipotética del hombre medio ${ }^{87}$. En el caso que nos ocupa sería la vivencia de esa mujer concreta en contexto de VIF.

\section{c) La situación de violencia intrafamiliar como desencadenante del miedo insuperable}

La mujer víctima de malos tratos vive un proceso psicológico complejo que se desarrolla en el contexto de una violencia cíclica. Esto determina, primero, que la mujer no sólo viva en un ambiente de temor, o miedo, constante, sino que también pueda aprender a prever episodios de violencia ${ }^{88}$, por lo que es capaz de identificar los factores que llevan a la violencia de su marido: que la comida no está lista a la hora, que salió sin avisarle a comprar lejos de casa, que se maquilló más de lo habitual, etc. La importancia penal de este factor es importante, porque permitiría comprender el por qué a pesar de que la agresión del marido no se esté produciendo (físicamente) en un

\footnotetext{
${ }^{83}$ Garrido Montt, M. ob. cit., p. 317.

${ }^{84}$ Mir Puig, ob. cit., p. 613.

85 Así Cury, ob. cit., p. 458, Garrido Montt, M. ob. cit., pp. 317-318.

${ }^{86}$ Garrido Montt, M. ob. cit., p. 317.

${ }^{87}$ En esta postura, que compartimos Politoff, S.-Ortiz, L. ob. cit., pp. 148-149, Prambs, J. ob. cit., p. 233.

${ }^{88}$ Esto es lo que en EE.UU. se denomina "síndrome de la mujer maltratada" y que ha servido en ocasiones para excluir la responsabilidad penal en base a la apreciación de un trastorno o enajenación mental transitoria. Ampliamente Larrauri, E. Verona, D. ob. cit., pp. 23 a 28.
} 
determinado momento, la mujer la percibe como inminente. Otra de las características de este proceso psicológico es que la mujer desarrolla un sentimiento de "indefensión aprendida”, sentimiento que afecta la percepción de la realidad y que puede llegar a tener relevancia en el ámbito de la culpabilidad, y en especial para no exigir a la mujer una conducta distinta. Si la mujer se sabe indefensa per se frente al marido, es más que probable que al sentir miedo de ser golpeada, vejada o de perder la vida, reaccione de manera violenta impulsada por el miedo y no pueda superarlo.

En este contexto emblemática es la sentencia de la Corte de Apelaciones de Chillán de $1954^{89}$, la que absolvió a una mujer que mató a su marido mientras éste dormía. La Corte consideró el informe pericial que describió a la víctima: "una constitución paranoica desde niño, ... hipersensible, aprehensivo, mandón y prevalente [...] bebedor compulsivo [...] los incidentes más graves se producían cuando llegaba embriagado. La torturaba física y moralmente". En relación a la mujer el informe señaló: "su acto no fue racional, fue un impulso instintivo de defensa de sí y de su hijo que cursó por la locura transitoria que le produjo el maltrato y asesinato frustrado de su marido, aplazado para cuando hubiera luz... su acto fue una descarga de tensiones emocionales que originó la agresión de su marido (...) no cabe duda de que... fue presa del miedo, miedo que, atendida la certidumbre que la mujer tenía de su muerte, es insuperable porque concurren en él los requisitos de la inminencia, gravedad, injusticia e inevitabilidad, estados de conmoción violenta que fue provocada por un acontecimiento externo dependiente de los hechos de un tercero, que le produjeron el raptus emocional; ...su instinto de conservación e integridad física le privaron de su voluntad para actuar libremente en forma racional".

También la Corte de Apelaciones de Santiago ha acogido la eximente: "Si la reo fue objeto de malos tratos por parte de su cónyuge, siendo agredida física y síquicamente delante de testigos y aun de sus propios hijos; si la víctima se jactaba de mantener a otra mujer; si la noche de los hechos golpeó a la inculpada en dos oportunidades; y si, con posterioridad, al pretender ésta acostarse en el lecho común, la víctima trató de expulsarla expresando que "lo único que puedo hacer para sacarte de mi vida es matarte, yegua, infame, desgraciada, infeliz"; si posteriormente la víctima pretendió sacar un revólver, que guardaba cargado, pero la inculpada dio vuelta el arma frente a su marido y le disparó; debe concluirse que la reo está exenta de responsabilidad penal, por haber obrado impulsada por un miedo insuperable al cometer el hecho delictuoso [ ]. Si bien la exactitud del miedo insuperable, para constituir una circunstancia eximente de responsabilidad, es de difícil determinación, no es óbice para que los tribunales la ponderen con la debida prudencia. Aunque podría alegarse que la acción agresiva de la reo fue

${ }^{89}$ Sentencia Corte de Apelaciones de Chillán de 10-05-1954, Revista de Derecho y Jurisprudencia, Tomo LII, N ${ }^{\text {os. }} 9$ y 10, 1955 (Secc. Cuarta), p. 211. Cit en Alonso, A. El miedo insuperable y la fuerza o violencia moral e irresistible, Ediar Conosur. 1985, pp. 65 y 66. y en Celis, L., Análisis jurisprudencial de la eximente de responsabilidad criminal: el que obra violentado por una fuerza irresistible o impulsado por un miedo insuperable, memoria para optar al grado de licenciado en Ciencias Jurídicas y Sociales, Fac. Derecho, Universidad de Talca, 2001, pp. 46 y ss. 
anterior al ataque con que se le amenazaba, la conducta del marido y los malos tratos que sufrió, le permitían esperar la agresión; por esto, resulta aceptable que hubiera actuado por un temor cerval" ${ }^{\prime 9}$. En otra sentencia para acoger la eximente se acreditó en el proceso que la mujer tenía un nivel intelectual inferior y tendía a desorganizarse emocionalmente con mucha facilidad. Que el marido era un alcohólico que golpeaba a menudo a su cónyuge, existiendo procesos anteriores en su contra por lesiones en contra de su mujer: "El día de los hechos el marido llegó hasta su domicilio en estado de ebriedad y comenzó a insultar a su esposa, amenazando enseguida con darle muerte, por lo que ella retrocedió hasta tocar el mueble de cocinilla que le impidió seguir retrocediendo, si de él tomó un cuchillo que puso en ristre azuzando a su marido a que se lanzara sobre ella, para amedrentarlo, y si el marido al abalanzarse sobre ella para tomarla del cuello sin darle tiempo para quitar el cuchillo se lo ensartó en el pecho, debe decirse que la encausada obró por un impulso anormal sobre su voluntad, que le coartó su libertad de decisión, reduciéndola de un modo tal que, jurídicamente no fue posible exigirle una conducta diversa de la adoptada" 91 .

Común denominador en estos fallos es el traslado de la exención de responsabilidad penal desde una auténtica justificación (legítima defensa) a una mera exculpación (miedo insuperable), porque incluso en aquel fallo en que la mujer mata al marido mientras duerme podría llegar a sostenerse la legítima defensa (el marido había anunciado que la mataría al despertarse). Otro común denominador es que en todos ellos ya se vislumbra el reconocimiento a las características del proceso de violencia cíclica en contexto de VIF: el sentimiento de indefensión en la mujer, la previsión del episodio de violencia, etc.

\section{d) La confusión entre el miedo insuperable y el trastorno mental transitorio}

Ha sido común en la jurisprudencia española y también en la nacional ${ }^{92}$ el hacer similares miedo insuperable con trastorno mental transitorio, olvidando la línea fronteriza entre ambos: mientras en el trastorno mental transitorio el estado de enajenación mental domina la voluntad, en el miedo insuperable la voluntad no queda totalmente doblegada, sino más bien impedida de ser ejercida en condiciones normales. Como dice Mir: "El miedo no tiene por qué llegar a consistir en una situación subjetiva cuya vivencia prive al sujeto de su lucidez o fuerza de voluntad, al modo de un trastorno

${ }^{90}$ Revista de Derecho y Jurisprudencia, Tomo LV, N ${ }^{\text {os. }} 7$ y 8, 1958, Secc. Cuarta, pág. 147. En otro caso indicó: "Obra impulsada por un miedo insuperable la mujer que mata a su marido, si se considera, el estado de permanente temor en que ella se encontraba como consecuencia de los insultos y reacciones físicas de que era objeto, las amenazas de muerte repetidas y actualizadas en la frase "boy tenemos que arreglar en forma definitiva esta situación"la cual, si bien ambigua en cualquier caso, tenía un significado preciso en los autos-la tentativa de consumar amenazas de muerte, cuando menos en dos oportunidades; la violencia habitual de la víctima por su temperamento alcohólico. Sentencia Corte de Apelaciones de Santiago, 14-11-1950 (R. de C.P. Tomo XII, p. 78). Cit. por Alonso, A. ob. cit., pp. 69 y 70 .

${ }^{91}$ Sentencia Corte de Apelaciones de Santiago de 30-9-1969. Revista de Derecho y Jurisprudencia Tomo LXVI, 1969 Secc. Cuarta, p. 623. Reproducida en parte en Alonso, A. ob. cit., p. 73.

92 A este respecto, véanse sentencias citadas por Larrauri, E.-Verona, D. ob. cit., pp. 97 y ss. 
mental transitorio. Miedo no ha de entenderse como terror"... "el miedo insuperable no excluye la voluntariedad de la acción, sino que la priva de la normalidad necesaria para que pueda imputarse penalmente al sujeto"93. En la doctrina nacional, los autores están contestes en la distinción ${ }^{94}$. Sin embargo la jurisprudencia nacional desde la década del 50 y hasta ahora ha transitado por otros lares, de manera tal que si el informe psicológico de la mujer dice que la mujer no tiene un trastorno de personalidad o no tuvo en el momento un trastorno mental capaz de anular su inteligencia o su voluntad, es plenamente imputable. Por el contrario, si la mujer tenía el trastorno, se exime.

Así por ejemplo, la Corte Suprema en 1998 declaró: "Es un hecho de la causa que la enjuiciada recibía malos tratos físicos y de palabra, de parte de su cónyuge. Sin embargo, no se acreditó suficientemente en el proceso, que tal circunstancia, como tampoco el hecho de ser la encartada de naturaleza depresiva o tener personalidad anormal, ni todas estas situaciones en conjunto, hubiese determinado que actuara, en el momento que acaeció el hecho investigado, totalmente privada de la razón o violentada por una fuerza irresistible o impulsada por un miedo insuperable" ${ }^{95}$. También las Cortes de Apelaciones tienen los mismos razonamientos: “...Al momento de cometer su crimen la reo pasaba por un período de locura transitoria que le exime de responsabilidad" 96 . "El miedo puede considerarse como una fuerza moral o psicológica, y para que obre como eximente de responsabilidad criminal, es necesario que sea insuperable, lo que significa que la persona debe aterrorizarse hasta que se produzca en ella una perturbación psíquica"97. "El tribunal sobre la base de informes periciales calificó el hecho como resultado de una emoción violenta, de "naturaleza patológica", la cual "automatiza" y es "casi siempre incontrolable", "sin posible control voluntario" y "excluyendo la acción de su libre voluntad"98.

\section{e) La incorporación de requisitos ajenos a la eximente}

Otra línea argumental utilizada por la jurisprudencia para negar la concurrencia de la eximente in comento es la de exigir requisitos que la ley no consagra. Así por ejemplo, suele exigirse la concurrencia de un peligro de mal inminente o actual. Esta exigencia si bien ha sido considerada por la doctrina para poder comprender el origen del miedo tiene como contrapartida la prueba de la misma, lo que en casos de VIF es particularmente gravoso para la mujer, pues en general no hay testigos del maltrato. Esto se repite tanto

${ }^{93}$ Mir Puig, S. ob. cit., pp. 615 y 613.

${ }^{94}$ Por todos, Garrido Montt, M. ob. cit., p. 317.

95 Sentencia Corte Suprema de 15-12-1998, Rol 4021-98 (Valparaíso). Libro de Registro de Sentencias criminales de la Corte Suprema, diciembre 3-6, 1998.

${ }^{96}$ Sentencia Corte de Apelaciones de Chillán 10-05-1954, cit. Revista de Derecho y Jurisprudencia, Tomo LII, N ${ }^{\text {os. }} 9$ y 10, 1955 (Secc. Cuarta), p. 211. Cit en Alonso, A. ob. cit., pp. 65 y 66, y en Celis, L. ob. cit., pp. 46 y ss.

97 Sentencia Corte de Apelaciones de Temuco de 8-11-1958.

${ }^{98}$ Sentencia Corte de Apelaciones Santiago, 14-11-1950 (R. de C.P. Tomo XII, p. 78). Cit. por Alonso, A. ob. cit., pp. 69 y 70 . 
en Cortes de Apelaciones ${ }^{99}$ como en Tribunales Orales: "no se acreditó que la acusada haya estado en una situación que le haya provocado un miedo tan grande, que le causara pérdida de la noción de sus actos o el dominio de los mismos, la agresión de la que se dijo fue víctima, provocada por el ofendido, no fue acreditada. No se estableció que haya sido agredida, no se acreditó que haya efectivamente sido víctima de un ilícito, por ende, no es posible concluir unívocamente que la víctima haya provocado con su actuar, alguna agresión o amenaza de tal magnitud que haya generado en la acusada este miedo insuperable, para estimar que pudo provocar daños a su vida, integridad corporal o la salud o que temía un mal inminente" 100 .

En otras ocasiones, los tribunales niegan la concurrencia de la eximente por no existir proporcionalidad en el medio empleado, requisito que si bien es exigible en la legítima defensa, no lo es en el miedo insuperable ${ }^{101}$. Por último, otro de los argumentos que ha esgrimido la jurisprudencia para negar la concurrencia del miedo insuperable es atribuirle un supuesto carácter subsidiario, exigiendo por ejemplo el deber de huida o el haber acudido a otros medios ${ }^{102}$. Así, la Corte de Apelaciones de Rancagua: "la violencia intrafamiliar que la acusada habría sufrido... solo permite presumir que hubo discusiones y agresiones mutuas y quizás golpes que la mujer haya recibido, pero de manera alguna se ha probado una violencia de la gravedad y persistencia que permita suponer la obcecación ... y mucho menos si no se... probó, que la acusada haya intentado otras formas de solución del problema, que no la llevaran al crimen como la denuncia de los abusos ante las autoridades, o el abandono del hogar común"103. A este respecto, conviene tener presente que esta exigencia no deriva del texto, pues de exigirse se pierde de vista la naturaleza subjetiva de la exculpante, ya que "difícilmente puede esperarse de un sujeto aterrorizado

${ }^{99}$ Así por ejemplo, la Corte de Apelaciones de San Miguel: “...la procesada expresa que (él) siempre tomaba le daba malos tratos, la agredía cada vez que discutían. Luego de que ella hubiera intentado irse de la casa con su hija, nuevamente discutieron y se comenzaron a agredir, se tiraron el pelo, el occiso tomó un cuchillo y ella se fue encima de él y se lo quitó, no recuerda en qué momento se lo enterró, estaba totalmente descontrolada. Se deja constancia que la deponente presenta hematomas en ambos brazos. Insinúa haber actuado en defensa de su persona, argumento que el sentenciador no acepta por no encontrarse acreditado en autos, pues aparte de sus propios dichos no hay testigos presenciales que confirmen su versión". Sentencia Corte de Apelaciones de San Miguel de 24-04-1994, Rol No 142-94.

100 Sentencia TOP de San Antonio de 22 julio 2008, RIT 49-2008, RUC 0700509932-8.

101 Así por ejemplo, en Sentencia de la Corte de Apelaciones de Valparaíso de 1935: "No produce miedo insuperable, ni actúa una persona (la procesada) por fuerza irresistible, si reacciona a los insultos y amenazas de otro con violencia, haciendo uso de armas de fuego.”. Revista de Derecho y Jurisprudencia Tomo I, p. 213. Cit. en Alonso, A. ob. cit., p. 77, y Celis, L. ob. cit., pp. 61-62.

102 Así, la Sentencia de la Corte Suprema de 23-05-1963: "si da muerte a su marido encontrándose éste dormido, y sin amenazarla ya que en ese momento no la amenazaba peligro alguno, pudiendo evitar el mal sin cometer el delito bastándole que ante las amenazas del occiso se hubiera trasladado a dormir esa noche a casa de un vecino como lo hizo después de cometido el delito y enseguida separarse de su marido, aun cuando fuera por vías de hecho”. Rev. de Derecho y Jurisprudencia. Año 1963, Tomo LX, Secc. Cuarta, p. 67. Cit. En Alonso, A. ob. cit., p. 78.

103 Sentencia Corte de Apelaciones de Rancagua de 22-11-2004, Rol 221196. 
que realice un análisis de la situación para verificar las distintas posibilidades con que cuenta a fin de escapar de la situación que lo aterra" ${ }^{104}$.

\section{2. La fuerza moral irresistible (vis compulsiva)}

En otras ocasiones, las menos, la jurisprudencia ha considerado la concurrencia de la fuerza irresistible (vis compulsiva), configurándose a su respecto una causal de inexigibilidad. La vis compulsiva, o fuerza moral, se presenta en aquel que realiza una conducta típica y antijurídica para terminar con una violencia física o psicológica grave de que es objeto ${ }^{105}$. La medición de la "irresistibilidad" de esta fuerza presenta la misma situación que el miedo insuperable; la mayoría de la doctrina señala que el baremo de medición lo proporciona el "hombre medio" y otros estiman que la irresistibilidad debe medirse considerando el contexto en el que se presenta y las vivencias de cada sujeto. En el caso de violencia intrafamiliar la jurisprudencia en ocasiones ha acogido esta última postura, considerando las vivencias de la mujer maltratada. Así la Corte de Apelaciones de San Miguel en delito de parricidio de una mujer en contra de sus dos hijos aprecia la concurrencia de fuerza irresistible considerando el contexto de violencia intrafamiliar que la rodeaba ${ }^{106}$.

\section{COnClusiones}

El examen de las eventuales justificaciones o exculpaciones que pudieran concurrir en el caso de la mujer que mata al agresor familiar, arroja las siguientes constataciones:

1. No existen problemas, ni a nivel doctrinario ni a nivel jurisprudencial, para apreciar la existencia de una causal de exculpación, sea estado de necesidad exculpante (Roxin) o la causal de inexigibilidad de otra conducta conocida como "miedo insuperable" (jurisprudencia). Los tribunales en nuestro país tienden a acoger de

${ }^{104}$ Cury, E. ob. cit., p. 459.

105 Por todos, Politoff, S.-Ortiz, L. ob. cit., p. 148.

106 “...Movida por los malos tratos que le proporcionaba su marido, a ella e hijos y ante el hecho de que le había exigido que se retirara del hogar común, en circunstancias que dependía totalmente de él... creó en ella un estado emotivo que la hizo perder la facultad de inhibición e impidiéndole reflexionar en los resultados de su acción decidió intoxicarse con gas junto a sus hijos (...) Parece evidente que si un impulso emocional está considerado como circunstancia atenuante cuando es poderoso y acarrea una disminución de la exigibilidad de otra conducta, pueda operar también como causal eximente de responsabilidad penal en el evento de significar, por su especial intensidad e irresistibilidad, una ausencia total de exigibilidad. (Vistos 15) (...) Por tanto, la culpabilidad se ve excluida cuando el hechor ha sido "determinado en su obrar típicamente antijurídico por una 'vis compulsiva', que no logró vencer, causal ésta que por configurar la no exigibilidad de otro comportamiento en el concreto caso, obsta al juicio de reproche y motiva la absolución de la mujer".

Sentencia Corte de Apelaciones de San Miguel de 27-6-2001, Rev. de Derecho y Jurisprudencia, Tomo XCVIII, 2001 (abril-junio), secc. 4, páginas 88-92. 
manera mayoritaria esta última, causal que exige un estado de perturbación en las facultades intelectuales y volitivas, estado que no necesariamente debería concurrir, y que tampoco sirve a efectos de justificar o exculpar la conducta de los hijos que concurren a la muerte del maltratador familiar, pues el miedo insuperable es una circunstancia no comunicable a los partícipes. Sí existen graves problemas para apreciar la concurrencia de una causal de justificación, pues en aquellos casos en los que la legítima defensa no aparece como evidente, hay aprehensiones para admitir que la mujer que en situación de VIF mata a su agresor, está justificada. Y que por tanto, el ordenamiento jurídico "aprueba" que se mate al agresor. Nosotros creemos que a la luz de lo expuesto se trata de una conducta justificada y no exculpada.

2. Se estima que el camino para argumentar esta justificación, en nuestro derecho nacional, puede estar por dos vías: Reinterpretar los requisitos de la legítima defensa con perspectiva de género, o acudir al estado de necesidad defensivo, como causal supralegal de justificación. En ambos casos, es la exigencia de la actualidad de la agresión la que más problemas acarrea, pues la mujer que mata al marido agresor de ella y su familia, para poder actuar con éxito, debe esperar a que el ataque cese, aun cuando sea momentáneamente, o deberá anticiparse al próximo ataque.

3. Considerando que el fundamento de la legítima defensa es la existencia de una necesidad de defenderse, cabe indicar que: a) Agresión actual no sólo es la que se está produciendo, sino asimismo la inminente y la incesante. La inminencia de la agresión debe apreciarse en consideración al contexto y los conocimientos especiales por parte del que ejerce la defensa. b) La amenaza, aun la indirecta, en contexto de VIF, es una agresión inminente dado que pone en peligro próximo al bien jurídico, al tiempo que constituye un anuncio de agresión futura. El delito de malos tratos familiares constituye una agresión incesante, al menos para la libertad y seguridad individual de la mujer y los hijos, y por ende es "actual". En todo caso, conviene tener presente la necesidad de defenderse. Dar la debida importancia a la necesidad de defensa implica que en algunos casos el ataque puede no ser actual, pero la defensa es necesaria, como el caso del sujeto que tras agredir a su esposa sale para emborracharse no sin antes hacerle una advertencia, que permite a la mujer preveer un nuevo episodio de violencia próximo en el tiempo. En este sentido, la defensa no solo es para "repeler" sino también para "impedir" una agresión ilegítima. Y al revés, el ataque puede ser actual, pero la defensa no es necesaria, como ocurriría en caso de que la agresión consistiera en amenazas verbales de ser golpeada por parte de un agresor que ya se encuentra derribado en el suelo y sin posibilidades de levantarse para atacar.

4. Es posible tratar los supuestos de legítima defensa preventiva, como estado de necesidad justificante, dado que existe una necesidad de defensa frente a un peligro continuado cuya fuente es la conducta del maltratador. Siendo así, el estado de necesidad defensivo es la figura dogmáticamente apropiada para resolver situaciones como las que nos ocupan. Sin embargo no podemos obviar que en nuestro derecho la legítima defensa preventiva no existe como causal de justificación de la 
conducta, sino solo podría considerarse como una causa de atenuación de responsabilidad criminal (art. $11 \mathrm{~N}^{\circ} 1$ ) en base a una legítima defensa "incompleta", por lo que, habida consideración de las interpretaciones tan apegadas a la exégesis a las que estamos acostumbrados, político criminalmente parece poco viable tratar de conseguir en un tribunal la exención de responsabilidad penal de la mujer y los hijos por la vía del estado de necesidad defensivo como causal supralegal de justificación.

\section{BIBLIOGRAFÍA}

Alonso, A., El miedo insuperable y la fuerza o violencia moral e irresistible, Ediar Cono Sur, Santiago de Chile, 1985.

Bacigalupo, E., Derecho Penal. Parte General, Hammurabi, Buenos Aires, 2a ed. 1999, p. 369.

Baldó Lavilla, F., Estado de necesidad y legítima defensa, Bosch, Barcelona, 1994.

Bullemore, V. et al., Curso de Derecho Penal, Tomo II. Teoría del Delito, LexisNexis, Santiago de Chile, 2005.

Bustos, J.-Hormazábal, H., Lecciones de Derecho Penal, Trotta, Barcelona, 1999.

Campos, M.-Navea, K.-Olivos, F. Uxoricidio: una reacción de la mujer frente a la violencia intrafamiliar. Memoria para optar al grado de licenciado en ciencias jurídicas y sociales, dirig. por Loreley Friedman V., Fac. Derecho, Universidad de Chile, 2004.

Celis, L., Análisis jurisprudencial de la eximente de responsabilidad criminal: el que obra violentado por una fuerza irresistible o impulsado por un miedo insuperable. Memoria para optar al grado de licenciado en Ciencias Jurídicas y Sociales, Fac. Derecho, Universidad de Talca, 2001.

Cerezo Mir, Derecho Penal. Parte General. Edit. Universidad Nacional de Educación a Distancia, Madrid, $2^{a}$ edición, 2000.

Chocano Rodríguez, R., "Situaciones de necesidad de las que derivan causas de justificación: estado de necesidad agresivo y defensivo", disponible en http://www.unifr.ch/ddp1/derechopenal/anuario/an_2003_12.pdf (fecha consulta:22 -03-2010).

Cobo del Rosal, Vives Antón, Derecho Penal. Parte General, 4a edición. Conforme al Código Penal de 1996, Tirant Lo Blanch, Valencia, 1996.

Cury, E., Derecho Penal. Parte General. Ediciones Universidad Católica, Santiago de Chile, 2005,

Departamento de Estudios Defensoría Nacional: "La ley 20.066: determinación de la violencia psicológica, la procedencia de comisión por omisión y los presupuestos de admisibilidad de la legítima defensa". Minuta $N^{\circ}$ 2. Santiago de Chile, noviembre de 2009.

Garrido Montt, M., Derecho Penal. Parte General. Tomo II. Nociones fundamentales de la teoría del delito. $4^{\mathrm{a}}$ ed. Edit. Jurídica de Chile, Santiago de Chile, 2005.

Gómez Benítez, J.M., Teoría Jurídica del delito. Derecho Penal. Parte General. Civitas, Madrid, 1984.

Larrauri, E.-Verona, D., Violencia Doméstica y Legítima Defensa. Edit. EUB, Barcelona, 1995, p. 16. LuZón PeÑA, D., Aspectos esenciales de la legítima defensa. Bosch, Barcelona, 1978, $2^{a}$ edición, 2002. Mir Puig, S., Derecho Penal. Parte General (Fundamentos y Teoría del Delito), $3^{\text {a }}$ Ed. PPU. Barcelona, 1996.

Novoa Monreal, E., Curso de Derecho Penal Chileno, Parte General. Tomo I., Edit. Jurídica de Chile, Santiago de Chile, 2005.

Politoff, S.-Ortiz Quiroga, L. et al., Texto y Comentario al Código Penal Chileno, Editorial Jurídica de Chile, Santiago de Chile, $1^{\text {a }}$ edición, 2003. 
Prambs, J., El tipo de culpabilidad en el Código Penal chileno: una visión sistemática normativa y positiva. Metropolitana, Santiago de Chile, 2005, pp. 232 y ss.

Puente Segura, L., Circunstancias eximentes, atenuantes y agravantes de la responsabilidad criminal, Colex, Madrid, 1997.

Rioseco, L., "Culminación de la violencia doméstica: mujeres que asesinan a sus parejas-defensas penales posibles”, en Facio, A-Fries, L. (Eds.), Género y Derecho, Colección contraseña, Estudios de Género, Serie Casandra LOM Ediciones/ La Morada, Santiago de Chile, 1999, pp. 707-735.

Roxin, C., Derecho Penal. Parte General. Tomo I.: Fundamentos. La estructura de la teoría del delito, Trad. y notas DM. Luzón Peña, Miguel Díaz y García Colledo, Javier de Vicente Remesal, Civitas, Madrid, 1997.

Silva Sánchez, J. M.-Baldó Lavilla, F.-Corcoy Bidasolo, M., Casos de jurisprudencia penal con comentarios doctrinales, Bosch, Barcelona, 1997.

Zaffaroni, E.R., Derecho Penal. Parte General, Ediar, Buenos Aires, 2ª edición, 2002. 